\title{
Geleneksel Kent Dokusunun Korunması: Çankırı Örneği*
}

\author{
Gamze SEÇKIN GÜNDOĞAN ${ }^{1}$
}

Öz

Geleneksel dokular tarih boyunca birçok uygarlığa ev sahipliği yapan, kentlerin kültürlerini yansıtan ve kentin kimliğinin oluşmasında önemli bir role sahip olan yapılı çevrelerdir. Bir kentin geleneksel dokusu o kentin, tarihine, iklimine, topoğrafyasına, coğrafyasına, sosyolojik yapısına ve kültürel değerlerine bağlıdır. Osmanlı ve Cumhuriyet dönemlerine baktığımız zaman birçok geleneksel yerleşim alanları bu çerçevede tasarlanmıştır. Çalışma alanı olarak seçilen Çankırı kentinde Osmanlı mimarisini yansıtan geleneksel doku ve sivil mimarlık örneği yapılar bulunmaktadır. Bu yapıların bulunduğu kesim 09.06.1978 tarihinde kentsel sit alanı ilan edilmiştir. Çankırı evleri olarak bilenen bu evler 17. Ve 18. yy 'da ahşap ve kerpiçten inşa edilmiş 1-2 katlı yapılardır. Bu yapıların birçoğu günümüze kadar köklü bir bakım ve onarım yapılmadan gelmeyi başarmıştır. Ancak tarihi doku sağlıksız ve çöküntü bölgesi niteliği taşımaktadır. Kentsel sit alanlarının korunması, kültürel devamlılığın sağlanması ve yaşanılabilir mekânlar oluşturularak gelecek nesillere aktarılması önem arz etmektedir. Bu çalışmada Çankırı'daki geleneksel kent dokusunun ve sivil mimarlık örneklerinin gelecek nesillere aktarılması için korumaya yönelik önerilerde bulunulmuştur. Ayrıca Çankırı kentsel sit alanına ilişkin derinlemesine alan araştırılması, plan analizleri, haritalama ve literatür taraması yapılmıştır.

Anahtar Kelime: Tarihi çevre, Kimlik, Geleneksel doku, Koruma, Çankırı

\section{Conservation of Traditional Urban Pattern: Example of Çankırı}

\begin{abstract}
Traditional patterns are built environments that have hosted many civilizations throughout history, reflecting the cultures of the cities and have an important role in the formation of the city's identity. The traditional pattern of a city depends on its history, climate, topography, geography, sociological structure and cultural values. When we look at the Ottoman and the Republic periods, many traditional settlements were designed in this frame. Çankırı, chosen as a study area, is a small city located in Central Anatolia. In the city of Çankırı, there are traditional texture and civil architecture examples reflecting the Ottoman architecture. The section where these buildings are located was declared as an urban site area on 09.06.1978. These houses, known as Çankırı houses, are 1-2-storey buildings built from wood and adobe in the 17th and 18th centuries. Many of these structures have survived to date without a radical maintenance and repair. However, the historical texture is unhealthy and has the characteristics of a depression area. It is important to protect urban sites, to ensure cultural continuity and to create habitable spaces and transfer them to future generations. In this study, suggestions were made to preserve the traditional urban texture and civil architecture examples in Çankırı to be transferred to future generations. In addition, in-depth field research, plan analysis, mapping and literature review related to Çankırı urban site area were carried out.

Key Words: Historical environment, Identity, Traditional pattern, Protection, Çankırı

\footnotetext{
${ }^{1}$ Çankırı Karatekin Üniversitesi Çerkeş Meslek Yüksek Okulu, Mimarlık ve Şehir Planlama Bölümü, Çankııı

İlgili yazar/Corresponding author: gseckin@karatekin.edu.tr

* Bu çalışma 29-31 Ocak 2020 tarihleri arasında Kayseri Üniversitesi tarafından düzenlenen 3. Uluslararası Sosyal

Bilimler Kongresinde sözlü bildiri olarak sunulmuştur.

Gönderim Tarihi / Received Date: 18.04.2020

Kabul Tarihi / Accepted Date: 22.10.2020
} 


\section{GíRiş}

Kentlerdeki aşırı nüfus artışı plansız, çarpık kentlerin oluşmasına ve merkezdeki var olan dokunun zedelenmesine, tarihi, kültürel ve doğal değerlerin yok olmasına neden olmaktadır (Kuter, 2007, s.1). Değerlerimizin yok olması, kimliğimizin yok olması demektir. Bu nedenle kentlerin dokusu, kimliğimizin gelecek kuşaklara aktarılması için çok önem arz etmektedir.

İnsanların bir mekân üzerinde yaşamlarını sürdürdükleri yerler kentleri oluşturmaktadır (Keleş, 2016, 109). Kent kimliği ise, kentin kendine özgü nitelikleri taşıdığı, sosyal, kültürel, fiziksel, tarihsel ve doğal faktörlerle şekillendirilen, kentlilerin yaşam biçimini oluşturan bir kavramdır (Çöl, 1998, s.14). Günümüzde ise kentsel kimliğin zedelendiği görünmektedir. Kentte yapılan çeşitli müdahaleler kent kimliğini olumsuz yönde etkilemektedir. Bu durum kentin tarihsellik boyutuna ve kentsel belleğin sürekliliğine zarar vermektedir. Çünkü bir kent geçmişini yansıtan tarihi dokusu ile yenilikçi( yeni) dokusu kaynaştırılmadığı zaman tarihsel ve kültürel sürekliliği zedelenir ve kentin kendine özgü kimliğinin kaybolması tehlikesi ile karşı karşıya kalır. Bu durumda yeni bir kimlik kazanması için tekrardan büyük bir zaman dilimine intiyaç duyulacaktır (Birol, 2007, s.46). Kentlerin yaşayan bir tarih olduğu düşünülürse sürekli kendini yenilemesi ve değişmesi kaçınılmazdır (Arabacıoğlu, 2007, s.205).

Kent kimliği, tarih boyunca yaşanmış olayların mimariye dökülmesi ile günümüze kadar ulaşmıştır. Bu yapıların bir arada bulunduğu bölgeler geleneksel kent dokusunu oluşturmaktadır. Geleneksel kent dokusu, tarih boyunca farklı birçok kültürü bünyesinde barındıran ve karşılıklı etkileşim ile oluşan kentin kimliğini yansıtan yapılı çevrelerdir (Bahtiyar Karatosun, 2010, s.32).

Kentlerin kimliğini kentte yaşayanlar ve onların yaşam biçimi oluşturur (Çöl, 1998, s.14). Kent kimliğini oluşturan bileşenlerden olan; doğal çevreden kaynaklanan kimlik unsurları, kentin topoğrafyası, iklimi, bitki örtüsü (hayvan varlığı/ flora ve fauna) gibi çevresel unsurlardan oluşmaktadır. Beşeri çevreden kaynaklanan kimlik unsurları, bireylerin ve toplumların sahip olduğu değerler (somut olmayan kültürel miras) kent kimliğinin oluşmasında doğrudan bir etkendir. İnsan eli ile oluşan kimlik unsurları ise, kentte yapılmış olan anıtlar, geleneksel doku, sivil mimari eserler, parklar, yollar gibi düzenlemelerdir (Birol, 2007, s.47).

Konut insanların temel yaşam hakkı olduğu için geleneksel konutlarında kullanımı insanlarının yaşam hakkıdır (Gültekin, 2007, s.262). İnsanların yaşam hakkına müdahale etmeden geleneksel kent dokusunun gelecek nesillere aktarılması ve sürdürülebilir olması çok önemlidir. Bir kente yeni bir yapının yapılması ya da var olan yapının yıkılması kent kimliği göz önünde bulundurularak yapılmalıdır. Yapılan ya da yenilenen her yapı kentin geleneksel dokusuna zarar verilmeden yapılmalıdır (Birol, 2007, s.47).

Birçok medeniyetlerin uygarlıkların yansıması olan geleneksel kent dokuları, sadece bulundukları coğrafyanın değil tüm dünyanın ortak mirası olarak kabul edilmektedir. Bir kent sadece içerisinde bazı etkinliklerin yapıldığı, yaşamlarını kazandıkları alanlar olarak görülmemelidir (Çöl, 1998, s.13). Kentler tarihi çevreleri ile ele alınmalıdır. Tarihi çevreler, zaman içinde geçirmiş oldukları değişim ve ortaya koydukları kimliklerimiz ile günümüz şartlarına uyum sağlayabildiklerinde önem kazanmaktadırlar (Arabacıoğlu, 2007, s.205). 
Bir toplumun mimari, sosyal ve kültürel değerlerini yansıtan tarihi çevrelerde bulunan geleneksel konutların kullanımı, bu konutların gelecek nesillere aktarılması için korunması ve restore edilmesi önem arz etmektedir. Geleneksel kent dokusunun onarım çalışmalarında eski ile uyum içinde olması çok önemlidir. Çünkü yapının tarihi dokusunu kaybetmesi kentin kimliğine ve dokusuna büyük ölçüde zarar vermesi demektir.

Kentlerdeki tarihi dokunun korunması sürdürülebilirliğin ve kültürel sürekliliğin devamı için önemlidir. Tarihi kentlerdeki kültürel miras, globalleşme, teknolojik değişme ve ayrıca zaman içinde toplumun olumlu veya olumsuz değişimin etkileri ile karşı karşıyadır. Koruma önceleri sadece bir anıt ile sınırlıyken zaman içinde dini, idari, askeri gibi önemli olan tarihi yapıların korunmasına yönelik ele alınmış olup günümüzde ise sadece tarihi ve kültürel varlıkları korumanın ötesinde kentsel bütünlükte koruma olgusu ortaya çıkmıştır. Koruma toplumun geçmişteki sosyal, kültürel, ekonomik değerlerini yansıtan, bu değerleri olduğu gibi bırakmayıp modern yaşama entegre etmektir (Türk,1995, s.3).

Çalışma alanı olarak seçilen Çankırı ili, İç Anadolu Bölgesinde bulunan iller arasında en küçük illerden birisidir. Son yıllarda kentleşmenin hız kazandığı Çankırı, geleneksel kent dokusunu kaybetme riski ile karşı karşıyadır. Hızlı kentleşme ve alınan imar kararları ile kent değişime uğramıştır. Modernleşme adına gerçekleştirilen bu düzen kent kimliğinin hızla yok olmasına ve yerini yüksek katlı yapılaşmalara bırakmıştır. Geleneksel kent dokusunu yansıtan sivil mimari eserler tahrip olmuşken, yeni tip yapılar kent dokusuna egemen olmaya başlamıştır. Sağlıksız ve estetik açıdan yoksun olan bu yapılar kimliğimizi unutmamıza neden olmaktadır. Oysa geleneksel kent dokusunu yansıtan mimari eserlerin yok edilerek alan kazanılması için bir araç olarak görmek yerine kültürümüzü, benliğimizi yansıtan, gelecek nesillere aktarılması gereken bir miras olduğu konusunda toplumun bilinçlendirilmesi gerekmektedir. Sağlıksız ve çöküntü bölgesi niteliği taşıyan Çankırı evleri bu bakımdan köklü bir bakım ve onarımın yapılması gerekmektedir. Bu araştırmanın ana amacı, geleneksek kent dokusunun korunması, sivil mimarlık örneklerinin gelecek nesillere aktarılması için kentsel sit alanına ilişkin sorun ve olanaklar belirlenerek çalışma alanına ilişkin öneriler getirmektir.

\section{MATERYAL VE METOT 2.1 Materyal}

Çalışmanın ana materyalini Çankırı kentsel sit alanı oluşturmaktadır. Çankırı kentinde 09.06.1978 tarihinde ilk kentsel sit alanı ilan edilmiştir. Ancak 01.03.2018 tarihinde kentsel sit alanın sınırının genişletilmesine karar verilmiştir. Bu alan Çankırı kentinin kimliğini yansıtan önemli bir alandır. Geleneksel kent dokusunu yansıtan bu çalışma alanında aşağıdaki kaynaklar kullanılmıştır.

- Çankırı Belediyesi İmar Müdürlüğünden elde edilen bilgi ve belgeler,

- Çalışma alanına ilişkin haritalar, fotoğraflar, planlar,

- Çalışma alanına ilişkin hazırlanan mekânsal analizler,

- Çalışma alanına ilişkin daha önce hazırlanmış olan makale, tez, kitap gibi literatür taramasından yararlanılmıştır. 


\subsection{Metot}

Çalışmanın yöntemi 4 ana aşamadan oluşmaktadır:

I. Aşama: Çankırı İlinin genel özelliklerinden ve kentteki kentsel sit alanından bahsedilmiştir.

II. Aşama: 2020'de kentsel sit alanında gerçekleştirilen arazi çalışmalarının sonucunda fotoğraf makinesi ile çekilen fotoğrafik belgeleme ile ile geleneksel kent dokusuna ait kimlik envanterleri oluşturulmuştur.

III. Aşama: Yapılan arazi çalışmaları neticesinde alana ilişkin tescilli yapı analizi, kat analizi, yapı durum analizi, yapı malzeme analizi ve doluluk-boşluk analizi gibi mekânsal analizler yapılmıştır. Bu analizlerde, Çankırı Belediyesinden alınan 1/1000 ölçekli hâlihazır harita altık olarak kullanıımış, bazı çizim programları kullanılarak dijital haritalar üretilmiştir.

IV. Aşama: Araştırma alanına yönelik geleneksel kent dokusunun gelecek nesillere aktarılması bağlamında ne tür sorun ve olanakların olabileceği tespit edilmiştir.

\section{BULGULAR}

\section{1 Çankırı Kentinin Genel Özellikleri}

Çankırı, İç Anadolu Orta Kızılırmak Bölümü'nde yer almış olup, etrafı, Kastamonu, Çorum, Ankara, Bolu ve Kırıkkale ile çevrili olan bir ilimizdir. Merkez ilçeyle birlikte toplam 12 ilçeden oluşmaktadır (Şekil 1). İ sınırları içerisinde 31 kentsel yerleşme ile 72 kırsal yerleşme vardır. 2019 Türkiye İstatistik Kurumu verilerine göre Çankırı ilinin toplam nüfusu 195.789 olup Çankırı Merkez nüfusu ise, 97.882'dir. Çankırı iklim özellikleri olarak kuzeyde Karadeniz güneyde ise İç Anadolu iklimine sahiptir. Yağış rejimi düzensiz olup, kuzey bölgelerinde yağış miktarı daha fazladır.

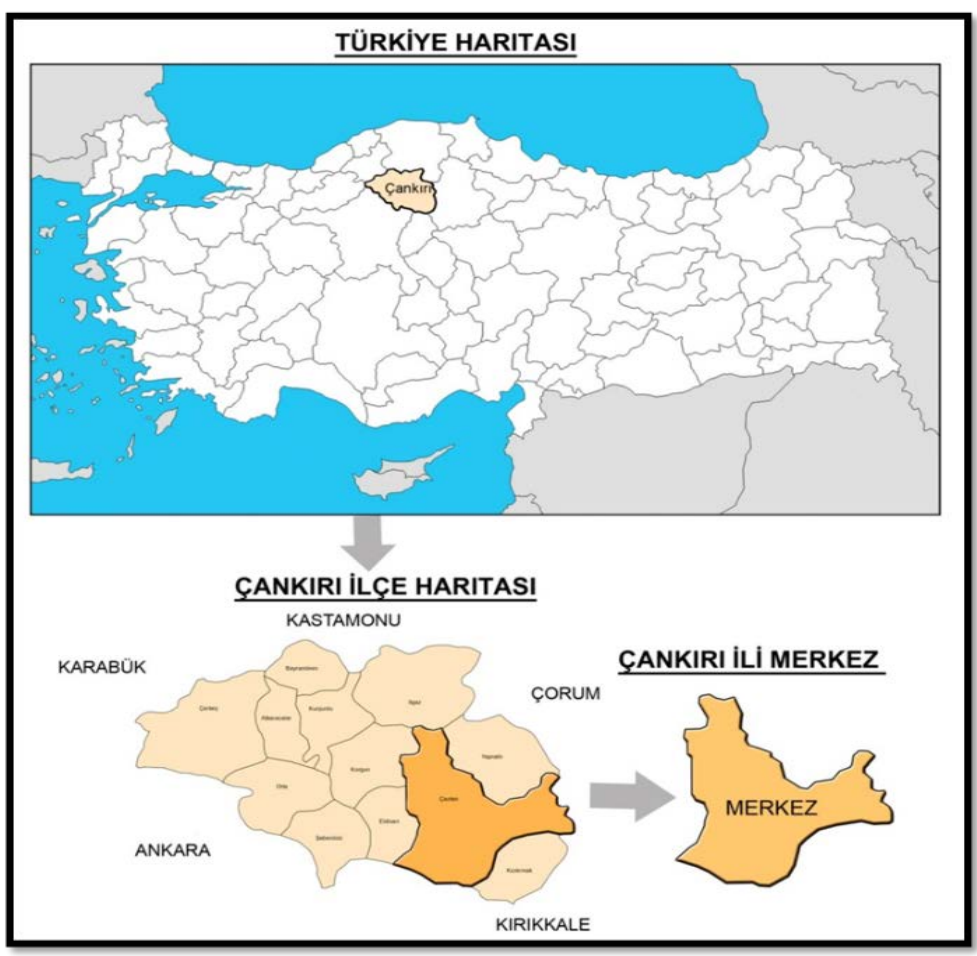

Şekil 1: Çankırı Konum Haritası 
Çankırı'nın tarihi M.Ö 3000'li yıllara eski Tunç çağına kadar uzamaktadır. O döneme ait çok fazla kazı çalışması olmamasına rağmen beş noktada eski tunç çağına ait kalıntılara rastlanmıştır. M.Ö 2000'li yıllarda Hitit İmparatorluğunun önemli yerleşim yerlerinden biriside Çankırı ilidir. Deniz kavimleri göçü nedeniyle Hitit İmparatorluğu yıkılarak güneydoğuya doğru çekilmiştir. Hititlerden sonra Çankırı' ya Frigler hakim olmuştur. Daha sonrasında sırasıyla Lidyalılar, Akhamenidler, Persler, Romalılar, Pontuslar, Bizanslar, Büyük Selçuklular ve Osmanlı devleti gibi birçok büyük uygarlığa ev sahipliği yapmıştır. (URL-1).

Çankırı kentinin ilk yerleşim yeri iki vadi arası olan Tatı Çay Vadisi ile Acı Çay Vadisi arasında kurulmuştur(Demirbağ ve Urfalıoğlu, 2019, s.74). Önceleri \%15'lik eğim ile Tatlı çay Vadisinin çevresine yerleşilirken sonrasında \%30'un üzerinde eğime sahip olan Acı Çay Vadisinin etrafında yerleşilmeye başlanmıştır. Yerleşmenin en kuzeyinde eğim çok dikleşmekte ve yerleşim alanının 100 m ötesinde Çankırı Kalesi yer almaktadır. Çankırı Kalesinde Roma Dönemi'nden kalma iskân kalıntıları, kaya mezarı ve pişmiş toprak kap parçaları ile Fatihi Emir Karatekin Bey'in türbesi bulunmaktadır (URL-2).

Çankırı kentine ait iki kent dokusu mevcuttur. Bunlardan birincisi Tatlı Çay Vadisinin kuzeyinde bulunan kentsel sit alanını oluşturan geleneksel kent dokusu iken bir diğer kent dokusu kentin güneyinde geniş sokakları, yüksek katlı yapılaşması ile yeni tip konutları ile yeni kent dokusudur (Şekil-2) (Kurter ve Erdoğan, 2007, s.37).

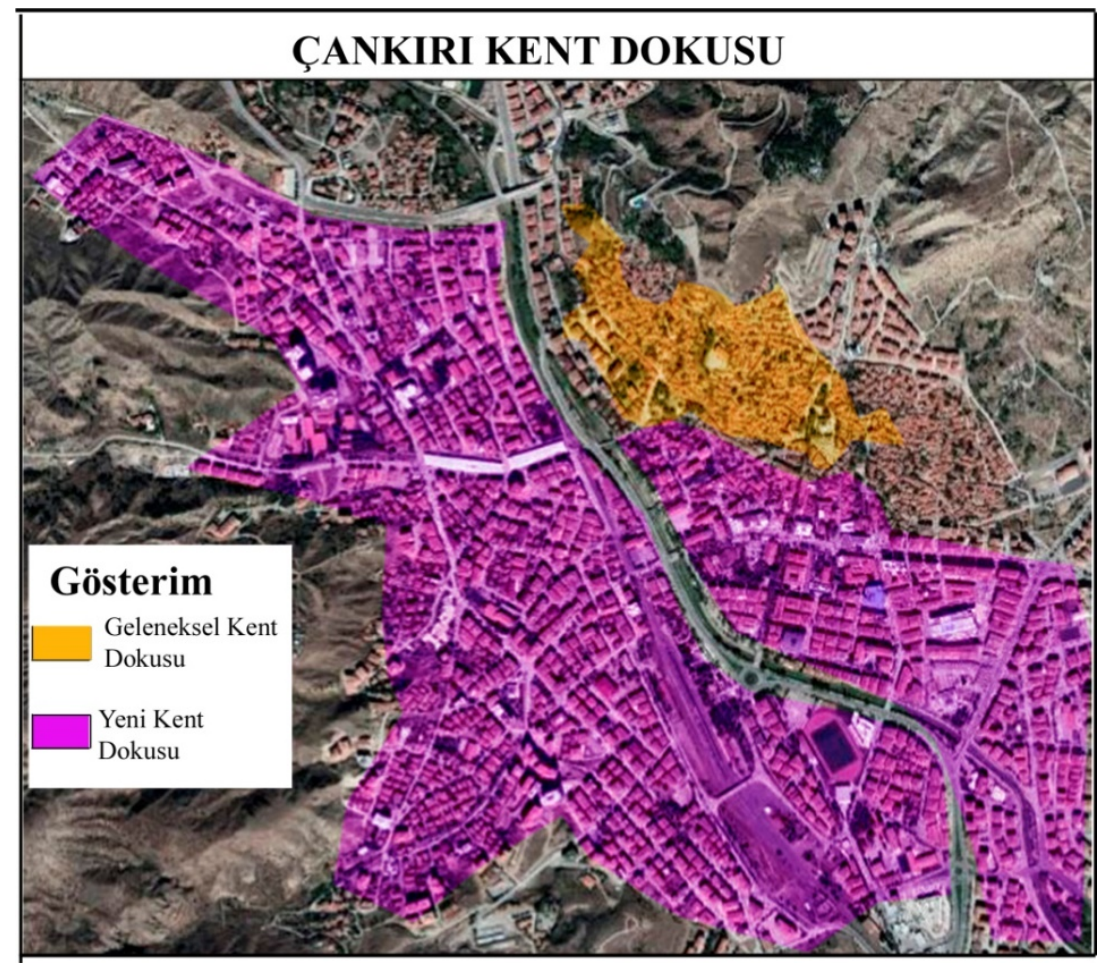

Şekil 2: Çankırı Kent dokusu

Çankırı kentsel sit alanında geleneksel kent dokusunu yansıtan sekiz mahalle dikkat çekmektedir. Bunlar Karataş, Ali Bey, Tabakhane, Mimar Sinan, Karatekin, İncilli Çeşme ve Cumhuriyet Mahalleleridir (Şekil-3). 


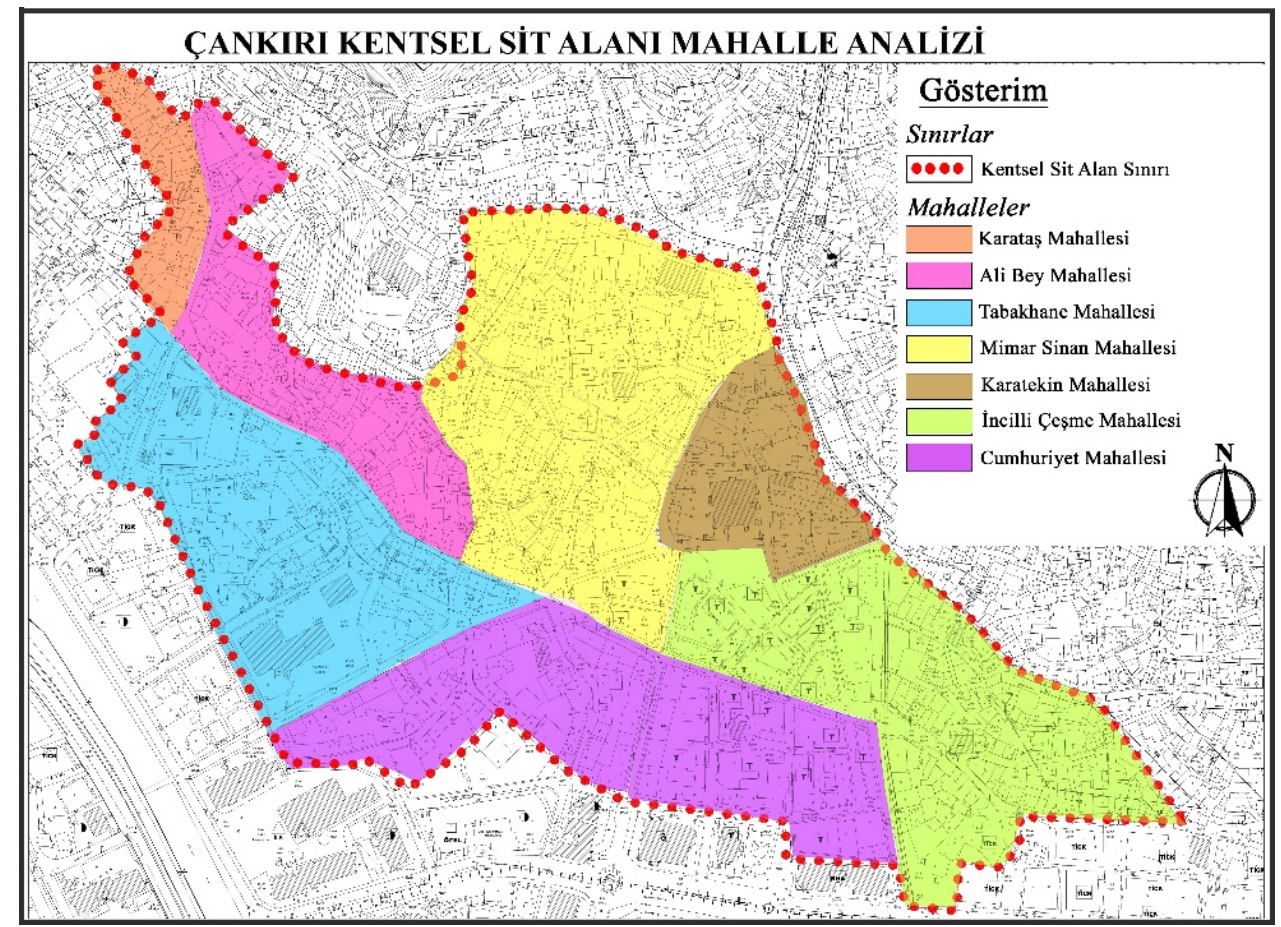

Şekil 3: Çankırı Kentsel Sit Alanındaki Mahalleler

\subsection{Mekânsal Analizler}

\subsubsection{Tescilli Yapı Analizi}

Çankırı iline ait 12.5 ha büyüklüğünde ilk kentsel sit alanı 09.06.1978 tarihinde ilan edilmiştir. Bu alan eski kent dokusunu oluşturan sokaklarının bulunduğu, anıtsal eserlerin yer aldığı, mimari ve tarihi değerler açısından önemli bir alandır. Mimar Sinan ve Karatekin Mahallesi sınırları içerisinde bulunan, Bakırcılar çarşısı, Pirinçciler çarşısı, Sultan Süleyman Cami Buğday Pazarı Camii gibi önemli tarihi eserlerin bulunduğu alanların kentsel sit alanı dışında kalması nedeniyle kentsel bütünlüğün sağlanması için 01.03.2018 tarihinde 257 sayılı Ankara 1 Numaralı Kültür Varlıklarını Koruma Bölge kurulu tarafından 2 numaralı koruma grubu (Kent ve çevre kimliğine katkıda bulunan kültür varlığı niteliğindeki yöresel yaşam biçimini yansıtan yapılardır) kapsamında kentsel sit alanına dahil edilmiştir (Çankırı Belediyesi arşivinden). Bu alan ile birlikte toplam sit alanı 19.8 ha olmuştur (Şekil-4). 


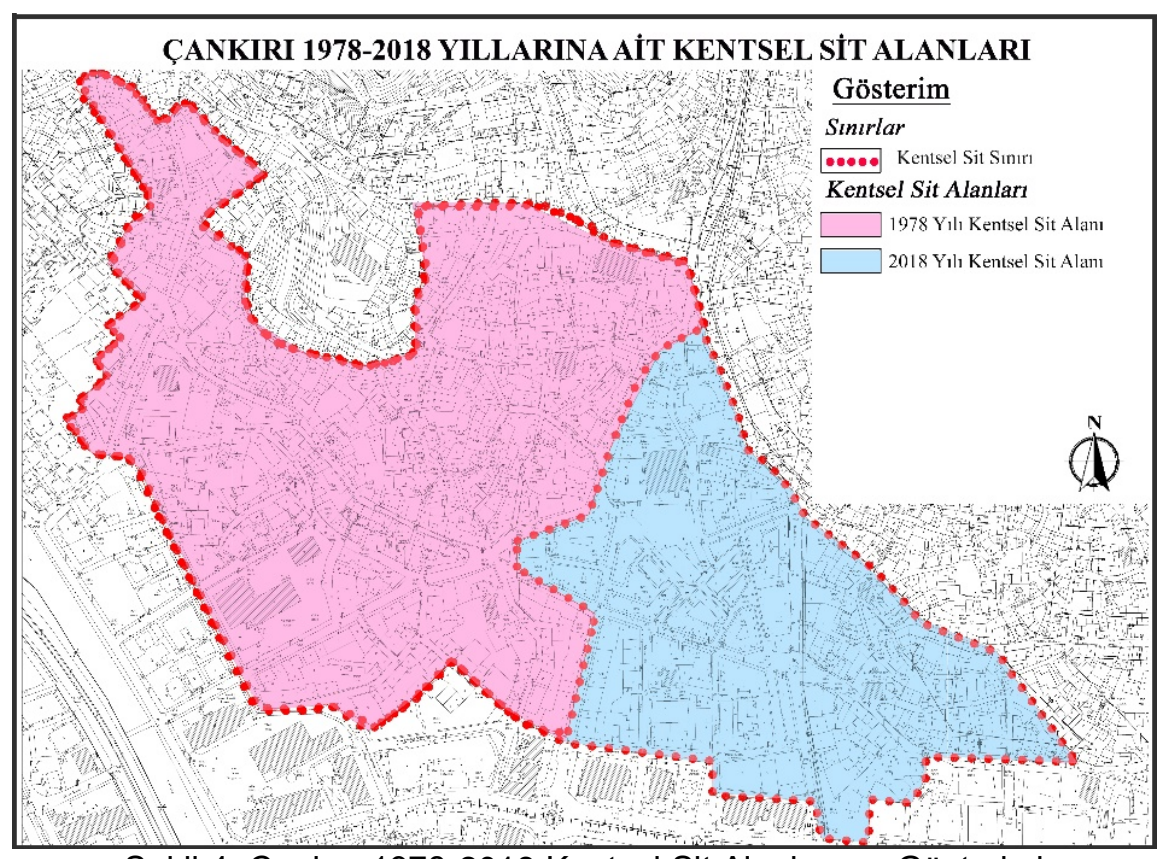

Şekil 4: Çankırı 1978-2018 Kentsel Sit Alanlarının Gösterimi

Çankırı kentsel sit alanı, Tatı Çay Vadisinin kuzeybatısında yer almaktadır(Kurter, 2007, s.215). Çankırı Kentsel Sit Alanı hem yaya hem araç ulaşımı olarak kent merkezinde bulunan önemli bir konuma sahiptir. Sokakların birçoğu çıkmaz sokak konumundadır ve yapıların birçoğu harabe ya da bakımsızdır. Kentsel Sit alanı içinde toplamda 77 adet tescilli yapı vardır. Bu tescilli yapıların 67 adedi sivil mimarlık örneğinde iken 10 adedi anıtsal yapı örneğindedir(şekil-5).

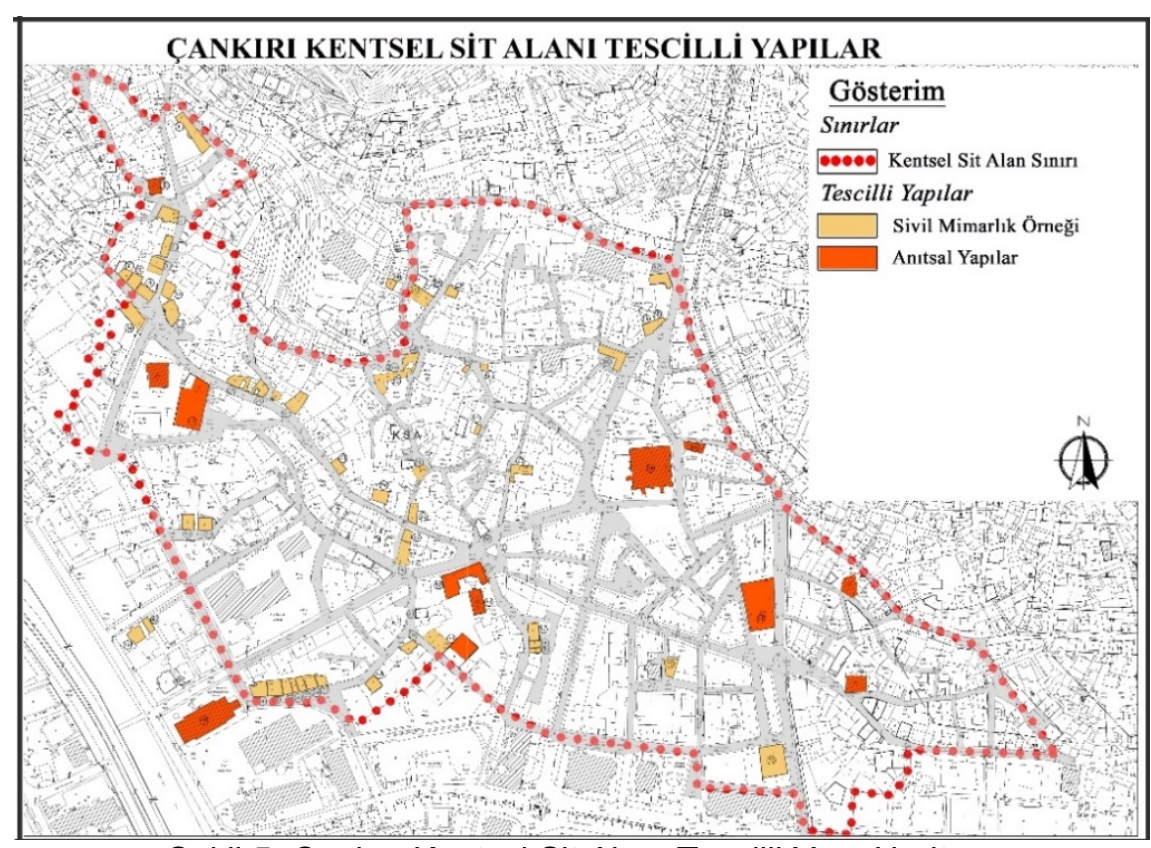

Şekil 5: Çankırı Kentsel Sit Alanı Tescilli Yapı Haritası

Çankırı kentsel sit alanı içinde bulunan sivil mimari yapılara ilişkin şekil 5'de bazı görsellere yer verilmiştir (Şekiil-6) 


\begin{tabular}{|c|c|c|c|c|c|}
\hline Adı & Tescil Yılı & Fotoğraf & Adı & Tescil Yılı & Fotoğraf \\
\hline $\begin{array}{l}\text { Buğday } \\
\text { Pazarı } \\
\text { Medresesi }\end{array}$ & 16.02.2007 & & $\begin{array}{l}\text { Buğday } \\
\text { Pazarı } \\
\text { Camisi }\end{array}$ & 16.02.2007 & \\
\hline Konut & 09.06.1978 & & Konut & 09.06 .1978 & \\
\hline Konut & 09.06 .1978 & & Civitlioğlu & 09.06 .1978 & \\
\hline Konut & 09.06.1978 & & Konut & 09.06 .1978 & \\
\hline
\end{tabular}

Şekil 6: Çankırı Kentsel Sit Alanına ait bazı Sivil Mimari Yapılar

\subsubsection{Kat Analizi}

Çankırı'daki yapıların kat yüksekliği incelendiğinde kentsel sit alanının çeperinde 4-5 katlı yapılaşmaların olduğu kentsel sit alanı içinde ise 1-2 katlı yapılaşmaların çoğunlukta olduğu gözlemlenmiştir. Çankırı Kentsel sit alanında bulunan yapıların kat adedi dağılımı, 307'si (\%31) 1 katlı, 605' i (\%61) 2 katı, 60' । (\%6) 3 katlı, 7'si (\%1) 4 katlı ve 8'i (\%1) 5 katıdır. Toplam yapı sayısı ise 987 olduğu gözlemlenmiştir (Şekil-7).

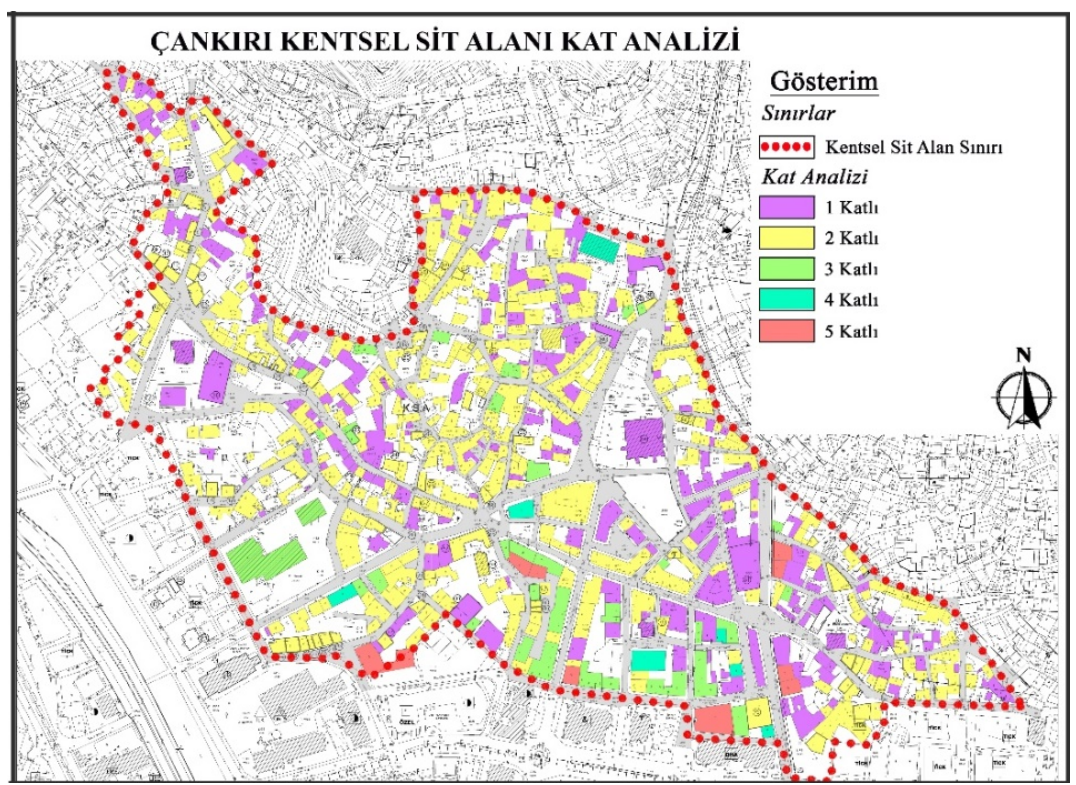

Şekil 7: Çankırı Kentsel Sit Alanı Kat Analizi 
Kentsel sit alanı içinde bulunan 2 katlı ve 1 katı yapıların genelde bitişik nizam olduğu ve yapıların topoğrafyaya uygun olduğu gözlemlenmiştir (Şekil-8).

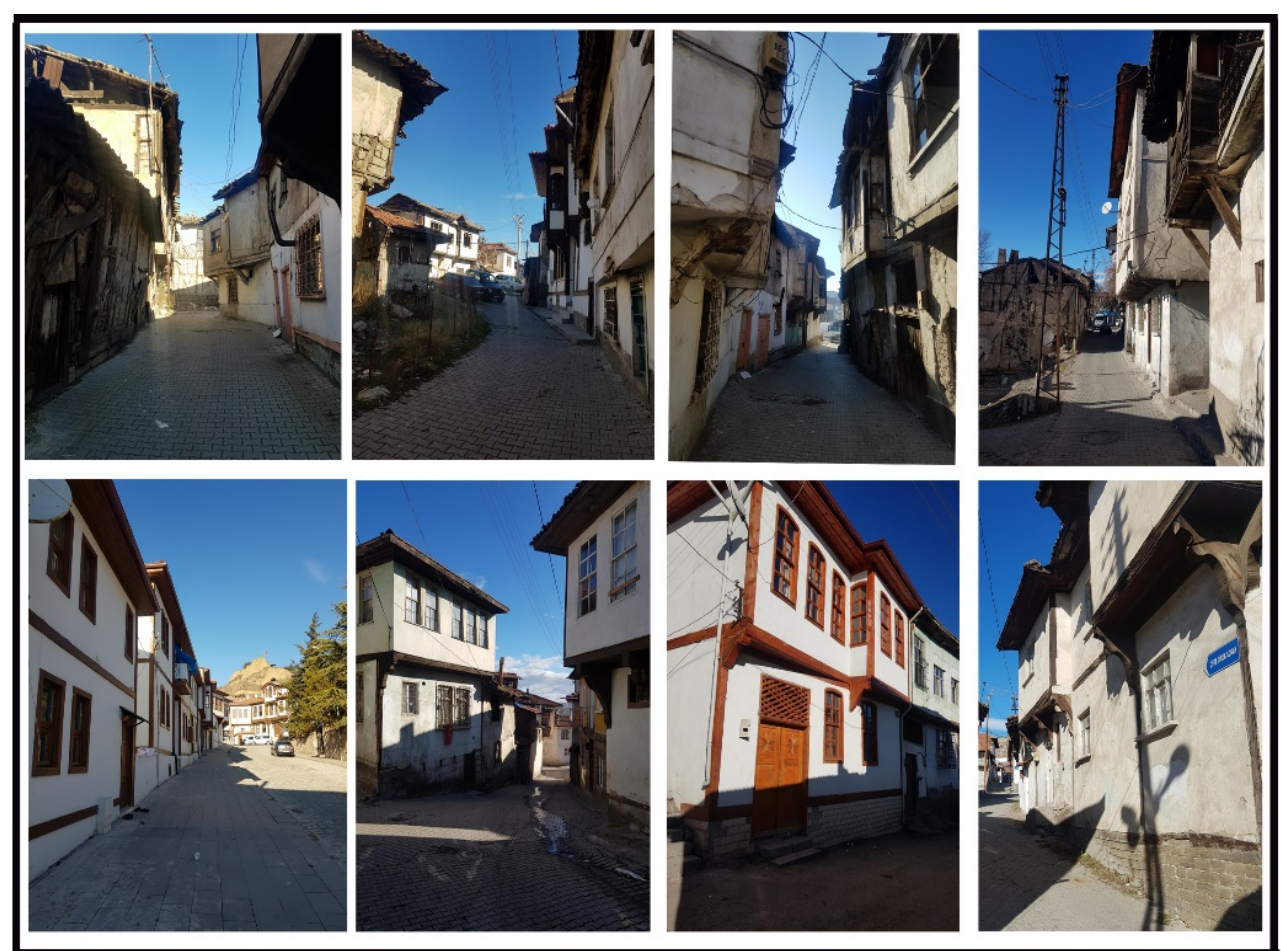

Şekil 8: Çankırı Kentsel Sit Alanı Yapı Tipolojisi

\subsubsection{Yapı Durum Analizi}

Çankırı kentinde yapı durumuna bakıldığı zaman merkezdeki yapıların genelde iyi durumdaki yapılardan oluştuğu ve bu yapılara bakıldığı zaman dış cephe kaplamasının onarıldığı veya yapıların yeni olduğu gözlemlenmiştir. Ancak kentsel sit alanı içindeki yapıların geneli kötü durumdaki yapılardan oluşmaktadır. Bu yapıların görüntüsü incelendiğinde hem sağlamlık açısından hem de dış görünüş açısından kötü yapılar olduğu gözlemlenmiştir. Çankırı Kentsel sit alanında bulunan yapıların, 72'si (\%7) iyi durumda, 529'u (\%54) orta durumda, 359' u (\%36) kötü durumda ve 27 ' si (\%3) harabe durumdaki yapılardan oluşmaktadır (Şekil-9). 


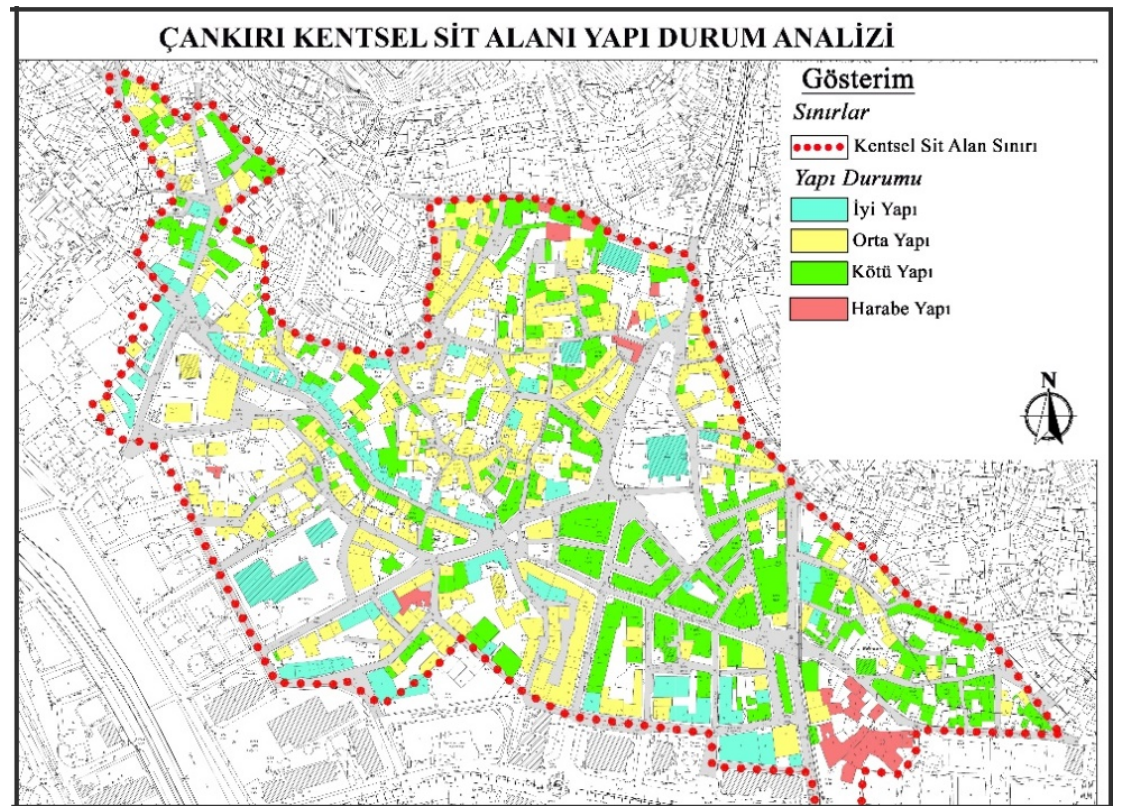

Şekil 9: Çankırı Kentsel Sit Alanı Yapı Durum Analizi

\subsubsection{Yapı Malzeme Analizi}

Çankırı kentsel sit alanı içinde yapılar, ahşap, betonarme ve yığma yapılar olarak dağılım göstermektedir. Bu yapıların 805'i (\%82) ahşap, 78' i (\%8) yığma ve 104' ü (\%10) betonarme yapılardan oluşmaktadır. Bu yapılarda dolgu malzemesi olarak kerpiç kullanılmıştır (Şekil-10).

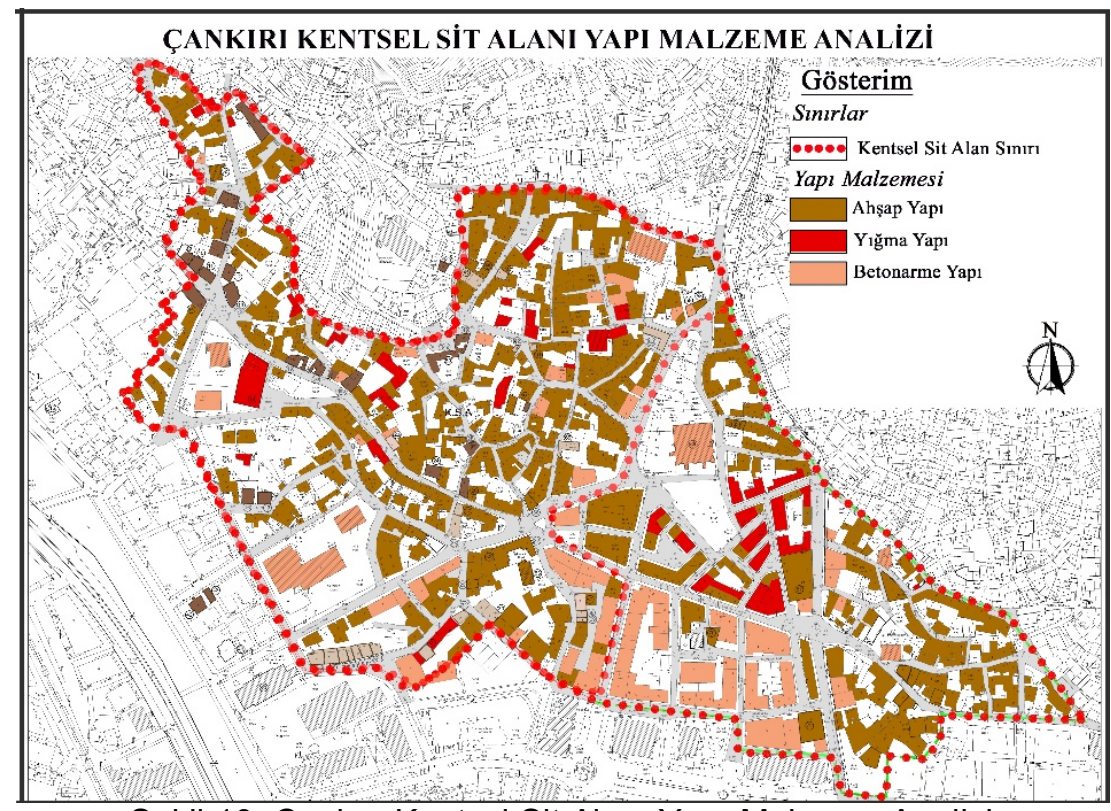

Şekil 10: Çankırı Kentsel Sit Alanı Yapı Malzeme Analizı

Kentsel sit alanı içerindeki yapıların çoğunluğunun ahşap yapıdan oluşması geleneksel kent dokusunun devamlılığı ve sürdürülebilirliği için önem arz etmektedir. Kentsel sit alanı içinde onarım çalışmalarının başlanması, yapıların yeniden kullanıma kazandırılması, Çankırı Belediyesi ve Koruma Kurulu tarafından yürütülen önemli bir çalışmadır (Şekil-11). 


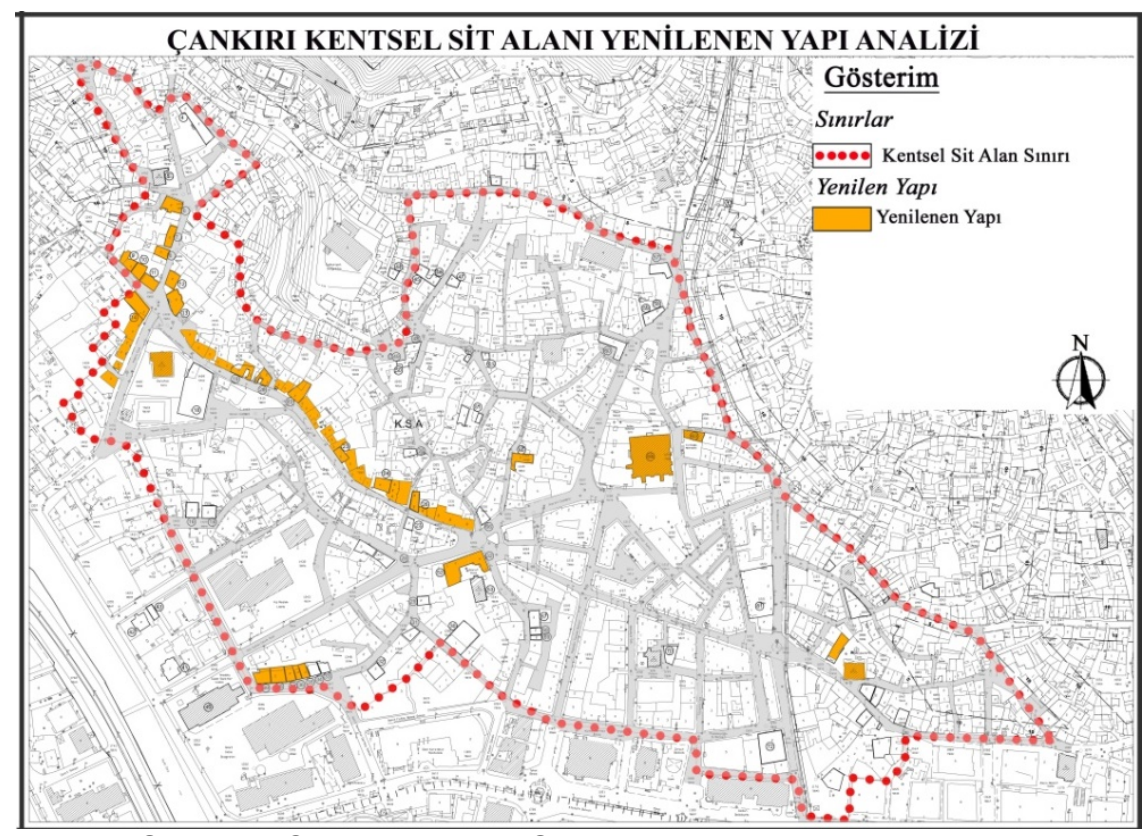

Şekil 11: Çankırı Kentsel Sit Alanı Yenilenen Yapı Analizi

\subsubsection{Dolu-Boş Analizi}

Çankırı kentsel sit alanı bitişik nizamlı yapıları, dar sokakları ve çıkmaz sokakları ile geleneksel Osmanlı mimarisini yansıtmaktadır. Çalışma bölgesinde toplam 19.8 ha'dır. Bu alanın 13.3 ha (\% 67) dolu 6.5 ha (\%33) ise açık alandan oluşmaktadır ( Şekil-12). Açık alanların genelini ise yapıların bahçeleri oluşturmaktadır.

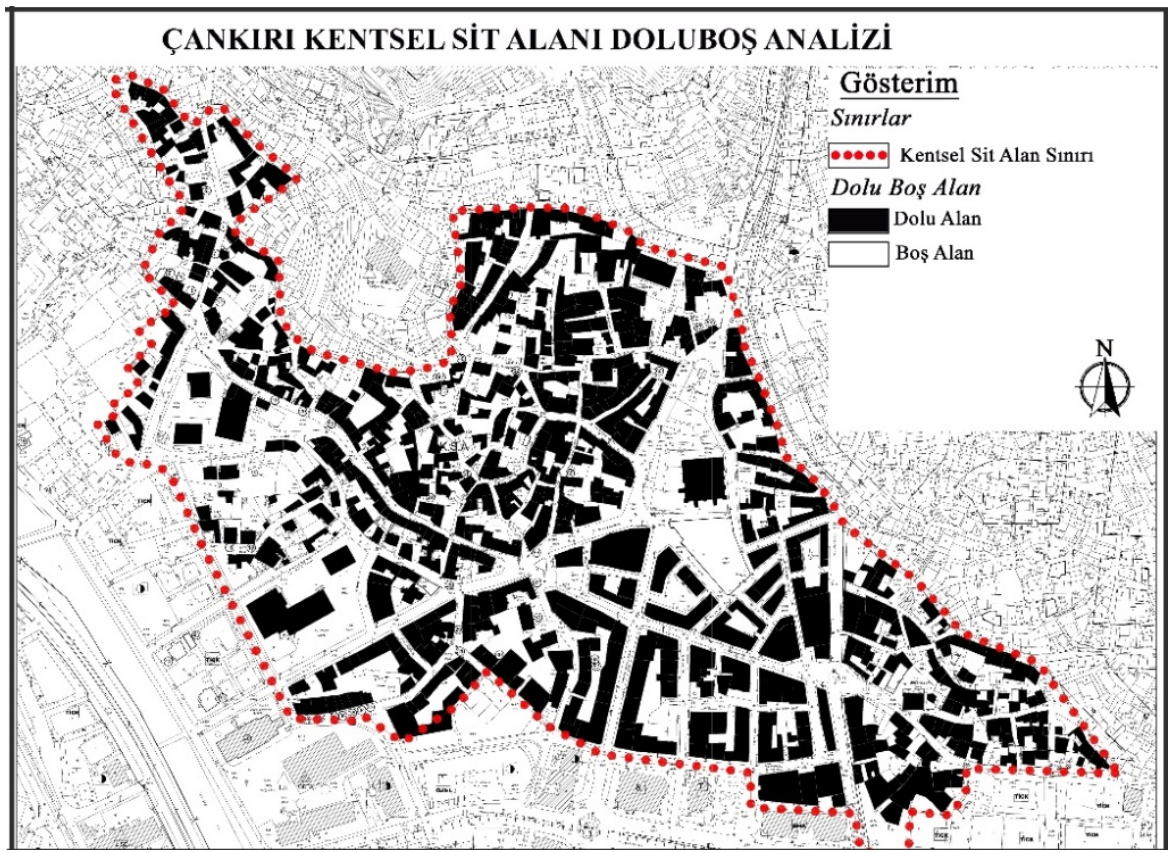

Şekil 12: Çankırı Kentsel Sit Alanı Dolu-Boş Analizi 


\section{3 Çalışma Alanına İlişkin Sorun ve Olanaklar}

Ülkemizde geleneksel kent dokusunun korunması ve sürdürülmesine yönelik birçok çalışma bulunmaktadır. Bu çalışmaların Çankırı kentsel sit alanında uygulanmadığı gözlemlenmiştir. Halkın daha çok apartmanlaşma, konfor talebi ve rant baskısı gibi etkenlerin, Çankırı kentinde korumaya yönelik gereken önemin verilmemesine neden olmuştur.

Güncel arazi kullanımı üzerinde etkili olan sosyal, kültürel, çevresel ve ekonomik değerler incelendiğinde ortaya çıkan Çankırı kentsel sit alanına ilişkin sorun ve olanaklar şu şekildedir.

\subsubsection{Olanaklar}

Çankırı kentsel sit alanına ilişkin olanaklar/potansiyeller şunlardır;

- Çalışma alanının kentsel sit alanı ilan edilmesi,

- Osmanlı mimarisini yansıtan yapıların fazla olması,

- Hareketli bir topoğrafyaya sahip olması,

- Yol genişliği ve yapı yüksekliğinin insan ölçeğinde olması,

- Anıtsal yapılara sahip olması,

- Yapıların bir birlerinin siluetini bozmaması,

- Tarihi sokak dokusunun olması,

- Turizm çekim potansiyelinin olması,

- Yerel yönetimin alana yönelik yenileme çalışmalarını gerçekleştirmesi gibi çalışma alanının korunması ve gelecek nesillere aktarılması için oldukça önemli olanaklara sahiptir.

\subsubsection{Sorunlar}

Çankırı kentsel sit alanına ilişkin sorunlar şunlardır;

- Koruma Amaçlı İmar Planının olmaması,

- 1. Dereceden deprem bölgesi olması,

- Turizm yönetim planının olmaması,

- Kent Ekonomisini canlandıracak büyük yatırımların yapılmaması,

- Kent dokusuna uymayan imar planlarının yapılmış olması,

- Plansız kentleşmenin, çarpık yapılaşmanın kent kimliğine ve kentsel dokuya zarar veriyor olması,

- Kentte otopark sıkıntısının olması,

- Araştırmaya, geliştirmeye ve yenilikçiliğe gereken önemin verilmiyor olması,

- Kentsel değerler hakkında bilgilendirme ve bilinçlendirme faaliyetlerinin olmaması,

- Tarihi yerlerle ilgili çalışma ve restorasyon için kaynak yetersizliğinin olması,

- Yapıların bahçeleri ile olan görsel ilişkinin yetersiz olması,

- Tescilli yapıların bakımsız olması,

- Kentsel yeşil alanların yetersiz olması

- Korumaya yönelik uygulama araçlarının yetersiz olması,

- Kültürel aktivitelerin yetersiz olması,

- Çalışma alanına ilişkin reklam çalışmalarının yetersiz olması,

- Kentsel sit alanının çevresinde 4-5 katlı yapıların olması, 
- Çalışma alanını yakınlarında yüksek katlı yapıların olması,

- Yapılar üzerinde orijinalliği bozan eklentilerin yapılmış olması,

- Araçların dar sokakları işgal etmesi ve yaya ulaşımını sıkıntıya düşürmesi,

- Kent mobilyalarının geleneksel dokuyu yansıtmaması gibi çalışma alanının korunmasını ve gelecek nesillere aktarılmasını olumsuz yönde etkileyecek sorunlara sahiptir.

\section{4- SONUÇ VE ÖNERILER}

Geleneksel kent dokusu kentsel çevrelerin önemli bir parçasıdır. Bu noktada önemli olan, geleneksel kent dokusunu yansıtan alanlar ile diğer kenti oluşturan alanların bir arada, bir biri ile uyum içinde planlanmasıdır. Geleneksel kent dokusunu yansıtan kentin kimliği için önem taşıyan bu alanların gelecek nesillere aktarımasının garanti altına alınması gerekmektedir. Burada koruma kavramı devreye girmektedir. Koruma politikalarının sürdürülebilirliğinin sağlanması, gelecek nesillere aktarılması, bütüncül bir kent planının oluşturulması için önemlidir. Çankırı kentinde, kentsel sit alanı bu bağlamda tam anlamıla korunamamıştır. Çalışma alanındaki geleneksel dokuların ev sahipleri ya da kiracılar tarafından kötü kullanılması, yapılara eklemelerde bulunulması, sokak cephesine yeni pencerelerin açılması gibi değişimlere uğradığı gözlemlenmiştir. Yeni yapı malzemelerinin kullanılması, çevre temizliğine gereken önemin verilmemesi çalışma alanındaki dokunun zedelenmesine neden olmaktadır. Diğer yandan yeni yapı adalarının geleneksel dokuya uygun olmadan inşa edilmesi, toplu konut çalışmalarının baskısı altında kalması, bütünleşik sürdürülebilir koruma ilkelerinin benimsenmemiş olmasının bir sonucudur.

Korunması gereken kentsel sit alanlarının en önemli sorunları göz önünde bulundurulduğunda bunlara yönelik;

- Yapılacak müdahalelerde ve yapılaşma kısıtlamalarında her yapı kendine özgü olarak ele alınması gerekmektedir.

- Yapılara yapılacak müdahaleler yapının geleneksel dokusuna zarar verilmeden yapılmalıdır.

- Geleneksel dokuyu zedeleyecek özgün olmayan yapılaşma kararlarından kaçınılmalıdır.

- Koruma, onarım ve yenileme çalışmalarında kent dokusunu bozmayacak yapı malzemeleri kullanılmalıdır.

- Sit alanı içerisindeki yapılara sonradan ilave edilen uygun olmayan eklemeler kaldırılmalıdır.

- Yapıların eski dokusuna uygun yenileme çalışması yapılmalıdır.

- Kültürel varlığın devamlılığı için doğrudan veya dolaylı olarak kamu kurum ve kuruluşlarının geliştireceği stratejiler, uygulamaya yönelik belirleyecekleri ilkelere dikkat edilmelidir.

- Kamunun korumada ki rolü kadar vatandaşlara da koruma bilinci kazandırılmalıdır.

Kentsel sit alanı içinde yapılan yenileme çalışmalarına bakıldığı zaman 19.8 ha kentsel sit alanında ki koruma çalışmalarının yetersiz olduğu gözlemlenmiştir. Bu kapsamda;

- Tescilli veya tescilsiz yapıların sokak cepheleri iyileştirilerek geleneksel dokuya uygun yenileme çalışmaları yapılmalıdır.

- Kentsel sit alanı içindeki iyi durumda olmayan yapıların yenileme çalışması yapılmalıdır. 
- Çalışma alanın içinde bulunan taşınmaz kültür varlıklarına atölye, sanat galerisi, kitap evi, sergi alanları gibi kültürel işlevsellik kazandırımalıdır.

- Kentsel sit alanı içinde Çankırı kentine ait ürünlerin sergisi ve satışı gerçekleştirerek turizme katkı sağlanmalıdır.

- Restore edilen yapılar turistlerin kalabileceği pansiyonlara dönüştürülerek işlevselliği artırılmalıdır.

- Yeni yapılacak plan çalışmalarında kentsel sit alanı dikkate alınarak çevresindeki yapılara yönelik kısıtlamalar getirilmedir.

- Kentsel sit alanı yayalaştırılarak araç trafiğine tamamen kapatıması gerekmektedir.

- Kentsel sit alanı içinde dolu boş analizi doğrultusunda yeşil alanlar artırılmalıdır.

- Belediye, Koruma Kurulu, Valilik gibi kamu kurum ve kuruluşlarının ortak hareket etmesi gerekmektedir.

- Konferanslar, seminerler düzenlenerek halkın bilinçlendirilmesi sağlanmalıdır.

- Korumanın, geleneksel kent dokusunun gelir getirici tarafı olduğu halka doğru bir şekilde anlatılmadır.

Sonuç olarak geleneksel kent dokusunu yansıtan Çankırı kentsel sit alanının korunması için yapılacak her türlü çalışmada kamu kurum ve kuruluşları arasında disiplinli bir çalışma yürütülmesi gerekmektedir. Koruma planları yapılırken disiplinler arası etkileşim içinde olunmalı ve arkeoloji, sosyoloji, tarih, mimarlık, iç mimarlık, peyzaj mimarlığı, şehir planlama, mühendislik gibi ihtiyaç duyulan her alandan bilgi alış verişinin yapılması gerekmektedir. Çağdaş ve gelişmiş olan ülkelerin önceliği tarihlerini korumak ve yaşatmak olduğundan kentlerimizde bulunan tarihi, kültürel dokuların korunması ve yaşatılması hem gelecek nesillere aktarılması açısından hem de çağdaş bir toplum olmamız açısından önemlidir. 


\section{5-KAYNAKLAR}

Arabacıoğlu, Pınar, "Tarihi Çevrelerde Yeniden Değerlendirme Kavramı”, YTÜ Mim. Fak. E-Dergisi, 2007, sayı 4, s.204-212

Bahtiyar Karatosun, Müjgân, "Geleneksel Dokularda Yeni Yapı tasarımı: Alaçatı Örneğinin İncelenmesi”, Ege Mimarlık, Ekim 2010, s.32-35

Birol, Gaye, "Bir Kentin Kimliği Ve Kervansaray Oteli Üzerine Bir Değerlendirme”, Arkitekt Dergisi, Kasım- Aralık 2007, sayı 514, s. 46-54

Çöl, Şölen, "Kentlerimizde Kimlik Sorunu Ve Günümüz Kentlerinin Kimlik Derecesini Ölçmek İçin Bir Yöntem Denemesi”, Mimar Sinan Üniversitesi, Fen Bilimleri Enstitüsü Doktora Tezi, İstanbul, 1998, s.13-14

Demirbağ, Uğur ve Urfalıoğlu, Nur, "Çankırı Merkez İlçe Geleneksel Konutların Cephe Biçimlenişi ”, Art- Sanat, Ocak 2019, s.71-100

Gültekin, Nevin, "Geleneksel Konut Dokusunda Kullanım Sürecinin DeğerlendirilmesiBeypazarı Örneği”, Gazi Üniv. Müh. Mim. Fak. Dergisi, Haziran 2007, Cilt 22, s. 261272

Keleş, Ruşen, "Kentleşme Politikası", İmge Kitabevi Yayınları, 15. Baskı, Ankara, Kasım 2016, s.109

Kurter, Nazan, "Çankırı Kenti Açık ve Yeşil Alan Varlığı İçinde Tarihi Kent Merkezinin Kentsel Peyzaj Tasarımı Açısından Değerlendirilmesi", Ankara Üniversitesi Fen Bilimleri Enstitüsü Doktora Tezi, 2007, Ankara, s.1-215

Kurter, Nazan, "Çankırı Kentsel Sit Alanının Peyzaj Tasarımı Açısından Değerlendirilmesi ”, Kastamonu Üniversitesi Orman Fakültesi Dergisi, Mayıs 2007, Cilt 7, s. $54-70$

Kulter, Nazan, ve Erdoğan, Elmas, "Çankırı Kentsel Sit Alanı Kaynak Potansiyelinin Saptanmasında Bir Yöntem”, Tekirdağ Ziraat Fakültesi Dergisi, 2008, s.35-44

Türk, Ali, "Kentsel Koruma Yaklaşımlarında Kentsel Kimliğin Korunması Isparta örneği", İstanbul Teknik Üniversitesi Fen Bilimleri Enst. Doktora Tezi, Ocak 1995, İstanbul, s. 3

URL-1 http://www.cankiri.bel.tr/sayfa-12/tarihi.php (Erişim Tarihi, 04.04.2020, saat, 22.45)

URL-2 https://www.kulturportali.gov.tr/turkiye/cankiri/gezilecekyer/cankiri-kalesi-ve karatekin-bey-turbesi (Erişim Tarihi, 04.04.2020, saat- 23.30) 